\title{
Regional Identity of Malaysian Sculptors based on Social Cultural System
}

\author{
Abdul Halim Bin Husain \\ National Academy of Arts, Culture and Heritage (ASWARA) \\ Malaysia \\ abdulhalim@aswara.edu.my
}

\begin{abstract}
Modern Malaysian Sculpture began to grow rapidly due to the emergence of sculptors who majoring in sculpture and graduated from the School of Art and Design, MARA Institute of Technology in 1980's. The early sculptors who started producing works of sculpture in Malaysia are Zakaria Awang, Ariffin Ismail, Mad Anuar Ismail, Ramlan Abdullah and many others. They studied in Art and Design at MARA Institute of Technology specializing in the field of sculpture. The second generation of sculptors in 1990's such as Zulkifli Yusof and Raja Shahriman has been working with a variety approach with ideas on the development of sculpture in Malaysia. They were introduced by new approach from their studies abroad, specializing in sculpture. Results from analysis of the shape and pattern of modern Malaysian sculpture are that they have a strong belief on the question of the origin of regional identity as a cultural identity towards the local environment. They believe that Malaysian Modern Art should be based on local cultural roots through cultural objects and meaning from local symbols.
\end{abstract}

Keywords—regional identity, sculptors, social cultural system

\section{INTRODUCTION}

By the end of 1970 and the subsequent years, the art of sculpturing began to grow rapidly due to the emergence of sculptors who graduated from the School of Art and Design, MARA Institute of Technology [1]

Artists who were majoring and specialization in sculpture either within or outside the country began to show their productions of great art work. The early sculptors who started producing works of sculpture in Malaysia are Zakaria Awang, Ariffin Ismail, Mad Anuar Ismail, Ramlan Abdullah and many others. They comprise of a generation of students who began their studies in Art and Design MARA Institute of Technology specializing in the field of sculpture. At the time, the role of higher education institutions and Art Galleries in the country is to act as a pillar for the dynamic developments of the works of sculpture in Malaysia.

Institutions that enlivened artwork of the homeland emerged as modern Malaysian artwork started to grow. The younger generation of painters and sculptors has been working with a variety of more serious approach. New ideas on the development of sculpture in Malaysia grew as they were introduced by the young lecturers who returned from studies abroad, specializing in sculpture.

New approach in the method based on new perspectives toward the art of sculpture flourished in Malaysian art. New values began to appear to interpret cultural meanings based on national challenges and the concept towards regional subject matter. The role of art institutions to produce graduates in the field of visual arts has accelerated the development of Modern Art in Malaysia, especially the art of modern sculpture. The 'National Cultural Congress' in 1971 and 'Seminar Akar-Akar Pribumi' 1979 have brought about many new interpretations in the context of modern sculpture in Malaysia that contribute to the development of regional concept in as an identity.

\section{A. Zakaria Awang}

Zakaria Awang is a sculptor who often uses themes based on religious advice to convey his message via the art of sculpturing. In his work, Zakaria Awang wrote on things that exist within the society. He features local objects written in a semi abstract form. They can still be recognized and most are based on man-made and natural objects.

There is only one art work where he used a figurative icon which is called 'Tugu Kebebasan' (Monument of Freedom) where Zakaria Awang used pigeons to deliver messages on genocide in Palestine. He also used the bridge to further strengthen the message in his work. In this work there are also two iconic six-pointed stars as a symbol of the Zionist Jews.

His work which is entitled 'Murakabah' used the 'Jawi' icon as a translation of the Quran to convey meaning. The 'Jawi' icon was composed by the sculptor in swirls in a crater drawn repeatedly based on the concept of chanting 'zikir'. The use of icons such as the 'crater' clearly gives meaning to the sociocultural system in the rural community. The sculptor managed to pick up objects in the setting of the rural community in this work.

In his work entitled 'Di Mana Cinta Abadi'(Where Love is Eternal), he used a 'table' and a 'chair' as a liaison with the art lover. In addition, the sculptor also uses icons in 'Jawi' to strengthen Malay symbols and tradition to portray his work. Approach towards religious advice in the works of Zakaria Awang can be seen with the use of Jawi. This can be seen in his work 'Alif, Lam, Mim', 'Murakabah', 'Di mana Cinta Abadi'(Where Love is Eternal) and 'Manisnya Senyuman'(Sweet Smile). In addition, the sculptor also uses contrasting colours with spontaneous but controlled strokes. In the sculpture titled 'Manisnya Senyuman'(Sweet Smile), Zakaria Awang used the 'stone' icon which is produced from tin. He also used the icons 'sticks' and 'Jawi' to be applied in his work. 
Next in 'Alif, Lam, Mim', he uses icons from the Quran verses, 'Alif, Lam, Mim' as a symbol associated with Islamic themes. Apart from that, the sculptor also strengthens the symbol of the Malay community in Malaysia, which is synonymous with Islam. The sculptor uses the approach of religious advice in the presentation of his work.

\section{B. Interpretation of the works of Zakaria Awang}

Based on the analysis and description of the artworks by Zakaria Awang, it is found that many of his works are based on human relationship. This can clearly be seen in works such as "Alif, Lam, Mim ',' Murakabah 'and' Dimana Cinta Abadi' (Where Love Eternal). It shows appreciation towards religious advice to the use of names in his title.

The icon-based display such as the use of Jawi icons which interprets verses of Al-Quran, clearly directs the works of Zakaria Awang to the divine aspect. The concept of divinity and nature adopted by sculptor is the same approach in the context of traditional art. In the context of traditional Malay art, the artists continually apply every area of life, whether from political or socio-cultural aspects in their works.

Religious advice becomes a responsibility for the sculptor in artwork when viewed in the context of himself as a sculptor. In addition to the sentences of the holy Quran used in works such as 'Alif, Lam, Mim,' and quotes verses on the work surface clearly leads to the question of the divine message.

In his work entitled "Alif, Lam, Mim ', the sculptor is obviously very aware of his existence as a Muslim and responsibility to society. Giving advice provides confidence to the sculptor in his relationship with the public. The idea is the same in his work entitled 'Murakabah'.

As a sculptor, Zakaria Awang produces works based on himself as a Muslim and Malay. Enlightenment on the responsibility as a sculptor as well as giving advice forms a union in his works. The concept of necessity as a Muslim that must take responsibility for his work in art leads him to produce his work with such an approach.

In addition to religious values in the form of advice on sight, Zakaria Awang also displays Malay values in his works. Both of these values become a strong grip to Zakaria Awang in his works. In the context of the culture, it is found that he uses cultural objects based on Malay tradition. His relationship with the physical environment based on the Malay social system led to the existence of icons and objects and such matters in his sculptures.

In his work entitled 'Murakabah,' he used objects such as the cauldron that is often used in the village ceremony and banquet. Similarly, in a work entitled 'Tugu Kebebasan' (Monument of Freedom) he uses objects or cultural bridge or wooden bridge, which is often found in the villages in our country. In a work entitled 'Murakabah', the sculptor uses the Jawi script associated with the Malays and the use of natural forms such as sticks and stones that can be seen in his work titled 'Manisnya Senyuman'(Sweet Smile).
The use of objects from traditional Malay culture and the Malay village atmosphere is his connection to physical environmental factors. Past experience, knowledge from social interaction makes allows Zakaria Awang to display his work which is very close to the Malay and Islamic values. Zakaria Awang also uses religious values as a representation of social values and in the larger world issues. This can be seen in his work entitled "Tugu Kebebasan' (Monument of Freedom) when a dead pigeon was displayed to reveal the loss of freedom in the Palestinian issue.

In the works of Zakaria Awang, it is also found that there is a link with the use of techniques taken by observing objects in the environment. The use of 'fiber glass' with techniques borrowed for the production of his sculpture is quite interesting. This can be seen in his work entitled 'Murakabah', 'Tugu Kebebasan' and 'Dimana Cinta Abadi'. Sculptor has linked the existing forms to further form the distinctive sculpture artwork.

\section{Ramlan Abdullah}

Ramlan Abdullah is a sculptor who often displays an abstract approach in the form of his sculpture work. His works often used material processing and related to issues on tradition. Processing various materials and processing materials towards perfection becomes the main gesture. This can be seen through studies on his works.

Ramlan Abdullah's work entitled 'Green Monumenta V' displays question on form as a whole. The preparation of composite materials with emphasis on highlighting the properties of materials reveals meaning that may be interpreted by anyone who views it. It is rather difficult to see a symbolic icon leading towards meaning in this work. Nevertheless, the sculptor has displayed glass and its charaterestics in telling the story on the meaning of the artwork. Ramlan Abdullah has arranged materials with the production of of form as a whole based on minimal structure but leading to perfection of the form. An understanding on the fundamentals of a well composed structure with the awareness of balance and unity make this work very dynamic.

In his work entitled 'Meditation-Gathering', Ramlan Abdullah also displayed problems based on materials processed to create an artwork that renders arrangement in unity. In this work, Ramlan Abdullah used the characterestics of the material to provide meaning to his work. There is the use of cut wood materials and arranged in escalation around a symbolic form bringing meaning to the narration of the work. He tends to use symbolic icons and structural arrangement in order to understand the meaning of the work as a whole.

The next sculpting work by Ramlan Abdullah is entitled 'Generation of Raw II' which also uses abstract approach as the sculptor emphasizes the characteristics of wood arranged neatly in order to provide the meaning of the work as a whole. 'Generation Of Raw II' features traditional image through wood element and stacking of firewood activities in the village. In this work, he has combined wood and stone, which 
has made it very harmonious and in addition, leads to the question of the origin-based identity and community.

There is also a large sized work of sculpture by Ramlan Abdullah entitled 'Growth' which was produced with industrial materials. 'Growth' is the work of public sculpture that used organic icons from natural resources that display elements of motion and dynamic growth. The use of granite in the works produced by Ramlan Abdullah became symbolic of the origins of the local community. Rhythm from the arrangement of metal plates expresses elements of growth. He interacted with the question of the revival and development of the ASEAN countries in the economic context and solidarity.

The sculpture titled 'Wahdah' which was presented in the public areas of Kuala Lumpur is the result of visible reflection on the development of Kuala Lumpur. Elements displayed by him seemed to symbolize the resurrection of economic, social and technological growth over time. The elements of sculptural material made of 'stainless steel' symbolizes the sophisticated latest advancements. The use of lines element that focuses towards unity is centered symbolically towards mutual success.

\section{Interpretation of meaning in the works of Ramlan Abdullah}

Based on the analysis on the works of Ramlan Abdullah, it was found that the sculptor has demonstrated various values in the production process of his work. Modern industrialization values exist in the works of Ramlan Abdullah. It is obvious when seen in the context of the current use of the material to produce his sculpture work. His works, entitled 'Growth', 'Tungku', and 'Green Monumenta V' have all used industrial materials such as iron, copper plate, and glass.

There is also a blend of Malay national where wood materials were aesthetically processed to create an interesting sculptural works of art. Wood is a material that is associated with the element of tradition and traditional values. This can be seen in his work entitled 'Generation of Raw II' and 'Meditation-Gathering'. Both the sculptures used wood completely. Wooden structure that exists in his creation entitled 'Generation of Raw II' also reminded the Malays in rural areas where firewood stacking activities were implemented in his work.

In the works of Ramlan Abdullah, there is a fairly strong relationship between the problems within oneself and in interpreting the problems of traditional form that exist in the modern appearance. Knowledge that the sculptor has acquired due to his education background is factor that enabled his to produce masterpieces with modern influence.

Ramlan Abdullah also used composite materials in the production of his works, which established the traditional values of natural and modern materials based on industrial materials. As for example, it can be seen in his work entitled 'Growth' when composite materials such as copper plate, steel and stone from nature were processed to produce a work of public art sculpture.
Similarly, in his work entitled 'Generation of Raw II' Ramlan combines stone, wood and iron as materials from nature in the context of the industrial value. The relationships between the physical environment and urbanization have greatly influenced the sculptor in his creations. This can be seen in the context of use of materials and techniques in his works that are moving towards industrialization.

\section{E. Zulkifli Yusof}

Zulkifli Yusof is a sculptor whose works often display as an installation works with the use of semi-abstract approach. His works have icons associated with a particular issue. There are many icons used in his work entitled 'Untitled'. There are the meaningful use of symbols and icons in his works. The use of icons such as chess pieces, bridge, water reservoirs, gate and colors with strong meanings in his work entitled 'Untitled'. Chess which is a symbol of community formation was evident in his work. Zulkifli Yusof is also a sculptor who is conscious in the structuring of strict form with formalistic aspects. The composition of materials and colors provide comprehensive meaning in his work.

There are icons comprising of alphabets that are printed on black cloth that wraps the wooden pieces used in his work entitled 'Dari Hitam Ke Putih' (From Black to White). The alphabets are meaningful symbols that provide the meaning towards access to knowledge. The wooden logs wrapped in black and white cloth is designed based on the bridge icon. The composition of lines based on wood wrapped with cloth provides the impression of dynamism to his work. Overall form emphasises a strong formalistic aspect and makes this work dynamic. Symbolically, the sculptor links the wooden bridge to the process where one has to go through to become better. This work is also formed with a surface filled with icons that narrates a story. Each angle is sculptured as if they are meaningful symbolically when the sculptor wisely places icons and imagery in his work.

In Zulkifli Yusof's work entitled 'Power I', many icons are processed to bring meaning into the work. In this work, the use of the chair is highlighted where it has been treated with wood and wrapped in white linen. A Chair provides a symbolic meaning of power to the sculptor and audience. Apart from that, there are icons of spear, bridge and a medal that in a union narrates a story for the artwork. The narration based on a combination of these icons leads to meaningful work entitled 'Power I'. This sculptural work as well as the other works of Zulkifli Yusof, explains aspects of storytelling through icons that meet his work. Zulkifli Yusof creates each imagery to form the overall meaning of his work which is quite powerful and dynamic.

Based on a literary work entitled 'Kisah Perlayaran Abdullah' ('The Story of Abdullah's Sailing), Zulkifli Yusof had created icons consisting of old images in his work. By processing old image using contemporary materials with specific techniques, he managed to produce a work of installation to meet the needs of a very dynamic area. The spacious lounge atmosphere with icons of the old image is 
formed based on a clear harmonized language towards themes and topics of narration.

\section{F. Interetation of meaning in the works of Zulkifli Yusof}

Findings from the analysis of the works Zulkifli Yusof, clearly illustrates the social, socio-cultural values in several works his sculpture. Zulkifli Yusof has produced lot of work based on his relationship with social issues among men with other men. In his work entitled 'Untitled', Zulkifli Yusof portrayed the value of respect to the leader. When people are willing to sacrifice time and energy to welcome leaders as illustrated in the structure of his work. On a similar note, in his work entitled 'Power I' when good leadership value exist it should be an example for someone who becomes the ruler. Awareness in relationships amongst the human race becomes the social issue which is often portrayed in his works.

Zulkifli Yusof portrays Malay values to in his works. This is clear when portrayed in his work entitled 'Kisah Pelayaran Abdullah'. In this work Zulkifli Yusof tries to raise issues on Malay values and the comparison with Malay values at the current time. The question of a different time, a different time space ratio has been described in different social systems. It is also closely related to the physical nature of the relationship between different time space.

Values in religion based on Islamic values were evident in his work entitled 'Do not Play During Maghrib'. It also highlights the value of culture among the Malays based on advice to family members to gather in the house. Works of sculpture by Zuklifli Yusof clearly have a combined value of which is quite close between culture, religion and the Malay race.

\section{G. Raja Shahriman Raja Aziddin}

Raja Shahriman Raja Aziddin is a sculptor who often uses abstract and semi abstract approaches in his work. Silat (a form of martial arts) style movements become very dynamic when processed through strict formalistic elements. Nevertheless, there are works by Raja Shahriman Raja Aziddin that do not use recognisable icons to have specific symbolic meaning. In his work entitled 'Watak',(Character) as an example displayed materials that renders arrangement in unity. The structure of the form process with the awareness on unity of material makes the work entitled 'Watak' very dynamic. Glass rendering becomes symbolic to something dangerous. On a similar note, the rendering of sharp steel rods forms the overall meaning in harmony.

In his work entitled 'Killing Tool', Raja Shahriman Raja Aziddin used the icon 'Keris' as a symbol in his creation. Steel is arranged to form a unified meaning. Ferrous materials or steel also becomes a symbol and as an overall significance in the formation of his work. The structure of the form is processed by the awareness of the unity is based on visual language seem to make this work quite dynamic.

Raja Shariman Raja Aziddin uses semi abstract approach in his work 'Gerak Tempur'(Combat Fighter'). The rendering of the icon is evident the work is based on Silat (martial arts) movement. However, the use of iron which resembles the shape of an unrecognizable figure represents the form of the works of Raja Shahriman Aziddin. He used the Silat movements as a guide in the production of his works. Elements of lines based on Silat arranged with iron rods in harmony and dynamic. The metal which was hard in the beginning is made to seem gentle by combining motion from silat.

The artwork entitled 'Nafas M6' (Breath M6) by Raja Shahriman Raja Aziddin clearly used a semi abstract approach as the form created portrayed figurine icons that have been styled. The sculptor has implemented elements of movement with forged iron. Combination of forged iron alongside lines organically forms a dynamic structure. The sculptor uses movement of objects in silat to produce his work. Creating centered structure in the middle of the artwork makes each arrangement of material and a movement towards controlled harmony.

The sculpture entitled ' Nafas M6' (Breath M6) is a work of sculpture that uses icons of figurines. It is the icons of figurines that have been simplified with appropriate materials and techniques. Elements of movement in the 'Silat' have been integrated in this work where subtlety of movement in 'Silat' becomes the focus to produce of this form of sculpture. Breath is a sign of the existence of the movement and the emergence of the movement is a sign of life. This is represented symbolically by lines and refined by the use of limited space.

The work entitled 'Bumi Penyatuan \& Makmur Abadi' (Earth Consolidation \& Eternally Progressive) uses an abstract icon. Element of lines and simple shapes make this sculpture very dynamic in nature. The combination of abstract art element which constitutes the basis seemed clear as unity exists in the form of a large circle that becomes the main focus of the work. Use of icons of natural vegetation which is portrayed with refined iron materials towards organic shapes represent the growth and continued development. This work presents elements of the art of refined language which is easy but in the abstract meaning of the theme.

\section{H. Interpretation of meaning in the works of Raja Shahriman Raja Aziddin}

Findings from the analysis of the works of Raja Shahriman Raja Aziddin, show that the cultural values and Malay values are reflected. Intense physical relationship with nature formed the work process for Raja Shahriman Raja Aziddin. His work entitled 'Gerak Tempur' (Combat Fighter) based on the motion that exists in the Malay martial art called 'Silat'. The concept of self-defense and 'combat' if needed is used as reference and is styled with a unique take on the elements of movement. In his work entitled 'Killing Tool', sculptor takes a cultural object that is the Keris to represent the Malays. His work entitled 'Watak' (Character) is one of the works that became a study interest in the context of human nature presented in abstract approach. 
In his work entitled 'Nafas' (Breath), Raja Shahriman displays much about life symbolically as it tells a lot about the religion and its relationship with the divine aspect. Breathing with the grace of God and this is manifested in his work with the approach of movement in Malay martial art.

In the work of public sculpture entitled 'Bumi Penyatuan \& Makmur Abadi', it clearly illustrates heroism and Malay supremacy, especially in the context of the State of Perak. This public work is created around the Perak State government building that has become a landmark to the State Government. The relationship between the physical environment and with oneself as well as with other human race becomes the core for Raja Shahriman Raja Aziddin's sculpturing process.

\section{Regional Identity of Modern Malaysian Sculptors through Symbolic Interaction}

Findings from the analysis on the symbolic interaction by sculptors, show that many interact with physical environment as their context of regional identity. Influence of physical environment can be seen existing in all works of the sculptors. The use of icon and symbols that exist in the sculptors natural environment becomes a source of inspiration and objects in their creations. In the context of modern sculptors in Malaysia, natural environment based on life style and cultural objects becomes the main source of reference for the sculptors. Sculptors interact with the environment. Apart from that, sculptors interact symbolically with the issues and the themes of humanity. The production of work based on advice amongst each other becomes an approach of the sculptors studied. The question can be customised through modern visual language. Apart from that the sculptors actually interact within their own selves. In some of Raja Shahriman Raja Aziddin's work, it can be seen that he create his sculptures by trying to express himself. It is similar to the works of Ramlan Abdullah that is directed to the form of problem solving within himself in solving the problem of form and responsibility in his creations.

\section{J. An Extra Aesthetics in the Context of Social Cultural System}

Findings from the analysis on the forms of sculptors studied, it is found that many express semi abstract presentation style. There are a variety of icons used by the sculptors studied to present their modern creations in Malaysia. It directs towards culture from local social community, especially the Malay community. Influence towards environmental aspects has resulted in many of the works formed with icons and symbols from environmental cultural objects. The question on knowledge towards the subject studied as icons becomes the main factor for the sculptors to be tied to the icons and other objects towards an approach.

Portrayal of icons studied by sculptors is more towards semi abstract approach. This is due to the influence of modern art that involves the use and arrangement of strict language based on the icons used. This is also the influence of prior knowwledge of the sculptors whereby all the sculptors had undergone a formal education in art where formalistic creations become the focus of the studied subject making the icon unique and having aesthetic and contemporary value.

The uniqueness of the sculptures studied lies in the strength of the sculptor to translate the essence of the object with the application of the values inherent in an integrated manner. Malaysian sculptors have the confidence of exposure that can be seen as recognized by the public clearly. In this study there is less use of extremist approach to shape the abstract art which makes it difficult for the audience to understand.

The sculptors involved in the study are those who acquired knowledge from arts education institutions. Art learning outcomes from the concepts that are processed with modern visual art language, thus, most of the works studied display a semi-abstract form of culture oriented object as a source of inspiration and the essence maintained that it still interpret the form in a flash.

Unique manifestations of structure are also the results of the work of sculptors' sensitivity shown as they used elements of language that seemed of universal standard for communication. Overall, the artwork in modern sculptures in Malaysia studied portrayed a form that comprises own strong characteristics and integrated be it as a concept or the presentations. They are based on local cultural objects existing in the community environment. Expression of unique objects as a result of creating the objects from observation by the sculptors towards the physical nature of the environment is very interesting. It directly shapes the identity of the artwork that represents the local socio-culture.

Creation of the structure is greatly influenced by the shape of the object studied by the sculptor and it maintained some form of structure to represent the structure of visual language that seemed universally acceptable.

Findings from the analysis on the modern Malaysian artworks selected for the study, show that there are characteristics where the sculptors portrayed large sized creations from local objects. The use of industrial material influences the techniques, where it gives a physical impact to the artwork. Besides, the main characteristics that exist from local cultural object is that, it forms the expressions to be presented on its own.

The modern Malaysian artworks selected for the study were presented in many styles, nevertheless, many uses installation styles. The artwork structure that builds on the strength and sustainability aspects of the elements of art and principles of design in orderly manner is the aspect preserved in modern Malaysian sculptures.

In the context of creating an artwork through symbolic interaction on a certain issue, the sculptors studied were influenced by the physical nature of the environment. Elements of Malay values brought by the sculptor mainly show belief and confidence towards Malay values and it is and it is as if an initial guideline and background or setting that is convincing. This is clear when we are able to see Jawi icons 
from the Malay world lifted and created modern Malaysian artwork. Similarly the icon of Malay weapons such as the keris that has become the Malay symbol, recreated its appearance to become and interesting and meaningful artwork.

The sculptor responds to natural environment occupied, and they had confidence in their presentation based on ethics and values based on things celestial objects taken from the local culture. Similarly, in the context of the use of natural objects or 'nature' which is also considered to establish their confidence in the existence of god. This can be seen in the works of modern sculpture studied according to the use of icons such as stone, wood and plants.

The sculptors whose works were studied provided feedback or 'response' and reacted to its physical environment with symbolic interaction through art forms created. Apart from that they also provided a reaction to the social aspects of society. Social issues arising from local environments and abroad were given response by the sculptor wisely based on icons and symbols that give meaning to their work.

There are works that are interesting as a result of reactions to social issues at global level. As for example, in the context of oppression of the Palestenians, the sculptor used slaughtered doves as a symbolic interaction of brutal events in Palestine. Similarly with the social issues in Malaysia was used to become a theme in modern Malaysian sculpting work such as the issue of power which was responded via symbols by the sculptor delicately and artistically.

In an analysis of the overall extra aesthetics of modern sculpture works of Malaysia, there are also symbolic interactions formed by the sculptor based on the work of other human beings. It has also become the main reaction of the other sculptors who were being studied. They often feature case objects that represent the local culture and in view of existing art forms generated by traditional towards Malaysian modern art display.

The use of works from Malay weapons such as the 'Keris', local cultural objects used in daily life such as the cauldron, bridge, stacked firewood in a village dan more that were used artistically by the sculptors in uncovering and lifting product of crafts towards the expression of moden style by taking the essence and philosophy as well as its mannerisms. It is also a personal concern and identifying oneself to the responsibilities that must be held as a sculptor and artist to represent the culture of the society as a whole. It also is a reflection of the essence of culture and heritage that is expressed by the sculptors for the delivery of modern style to be 'relevant' to the concept of the needs and requirements of modern and contemporary art.

Use of cultural objects in the community such as the 'Keris', rebab, spear, and much more is in fact illustrates the reaction of the sculptor symbolically in arrangements based on formalistic and semi abstract themes and issues towards the creation of the work.

Results from analysis of the shape and pattern of modern Malaysian sculpture, it is found that a strong belief on the question of the origin of cultural identity of the local community is held by the sculptors in Malaysia. The belief that art should be based on a sculpture of local cultural roots has been proven through objects and local symbols.

The next issue is the strength of the sculptor to view the physical environmental nature in their productions. As has been mentioned, the question of the environment that exists around each individual human affects all aspects of his daily activities, whether economically, socially or culturally. There are many themes that are produced by the sculptor who were studied where they used environmental issues that have always been the strength and confidence of the Malay community in particular. Contiguity between Malay human activities with their natural environment shows their belief in the greatness of God and it involves the aspect of divinity. It is customary for the Malay community in particular that always moved based on social systems that interact with their environment

The results of the observation of the shape and pattern of Malaysian works of modern sculpture show that the presentation needs to work towards integrative needs. This can be seen as a shared responsibility in raising aspirations and desires together in a group to create its own identity based on an ambition to uphold the question of national identity. Each sculptor who was studied did not arbitrarily create a sculpture with excessive self-expression but it was as if it is controlled and has specific goals for him to achieve. There were hidden agreement that was unintended formally in the work but were formed on the basis of the basic requirements in the formation of human biology in identifying themselves as a sculptor who knew their origins. It is also to meet the social needs of the work process implemented and the creation received by members of the public and audience of art to represent communities that they are proud of and so meet the integrative needs to meet their obligations in the artistry in the national context. Besides the significant increase in awareness among the sculptor to meet their responsibilities as artists and also as sculptors to the community, they helped shape social institutions.

The role of parties such as the National Art Gallery, art education Institutions, Ministry of Culture and Heritage and private galleries, helped and generated the sculptors and artists in Malaysia, especially to form their creations with a vision and self-esteem as well as its own distinctive identity representing Malaysia.

Action to produce sculptures and artistic works based on the issues of identity and personal identity are shaped by the conduct of the sculptor in the artwork. There are a variety of refined cultural objects that have been used by the sculptors in presentation, materials and techniques as well as modern formalistic combined by the sculptor to disclose the identity and to realize the ideals and form distinctive patterns to represent the appearance of the works of sculpture Modern Malaysia.

The sculptors with existing knowledge, stimulating environment and ritualistic elements held have been moving to 
diversify its creative activity with excellent control. The sculptors has to interact with the environment, the question of identity, the preservation of local culture and create with the procedures appropriate to ethics and compliance with the Malaysian community in producing works of sculpture that is distinctive and has a style and form of presentation, which can represent a whole art form of modern Malaysian sculpture.

\section{REFERENCES}

[1] Balai Seni Lukis Negara, Identiti Islam Dalam Senirupa Malaysia: Pencapaian Dan Cabaran: Kuala Lumpur, 1992.

[2] Balai Seni Lukis Negara, Kuala Lumpur(Identiti Islam Dalam Seni Rupa Malaysia: Pencapaian Dan Cabaran.

[3] Balai Seni Lukis Negara, Seni \& Kosmologi : Kuala Lumpur, 1996.

[4] Balai Seni Lukis Negara, Pameran Alam Melayu. Kuala Lumpur, 1999.

[5] Balai Seni Lukis Negara, Rupa Malaysia,Meninjau Seni Lukis Moden Malaysia : Kuala Lumpur, 2002.

[6] Balai Seni Lukis Negara, Wawasan Dan Idea, Melihat Semula Seni Lukis Moden Malaysia: Kuala Lumpur, 1994.

[7] Balai Seni Lukis Negara, Nafas, Seni Arca Raja Shahriman: Kuala Lumpur, 2004.

[8] Balai Seni Lukis Negara, Identiti Islam Dalam Senirupa Malaysia Malaysia, Pencapaian Dan Cabaran: Kuala Lumpur, 1992.

[9] Balai Seni Lukis Negara, Semangat Pelopor Seni: Kuala Lumpur, 1997.

[10] Balai seni Lukis Negara, Seni Dan Nasionalisme, Dulu \& Kini: Kuala Lumpur, 1999.

[11] Balai seni Lukis Negara, Siti Nurbaya...Warisan Seni Dan Tradisi: Kuala Lumpur, 2004.

[12] Balai Seni Lukis Negara, Pameran Seni Arca Kontemporari, Persoalan Tradisi Dan Kemodenan: Kuala Lumpur, 1996.

[13] Balai seni Lukis Negara, Imbasan Bakat Muda Sezaman: Kuala Lumpur, 1997.

[14] Balai seni Lukis Negara, Dimensi, Arca Dari Koleksi balai seni Lukis Negara: Kuala Lumpur, 2000.

[15] Balai Seni Lukis Negara, Pameran Seni Lukis \& Seni Khat : Kuala Lumpur, 1984.

[16] J. Berger, Ways Of Seeing. London: British Broadcasting Corporation and Penguin Books, 1972.

[17] U. Eco, Theory of Semiotic. Bloomington: Indiana University Press, 1976.

[18] E. B. Feldman, Varieties of Visual Experience. New York: Harry N.Abrams,Inc, 1992.

[19] R. Firth, Symbols Public and Private. New York: Cornell University Press, 1973.

[20] F. Frascina, and J. Harris, Art In Modern Culture. London: Phaidon Press Limited.Gombrich.E.H.(1972). Gombrich on The Renaissance: Vol.2, Simbolic Images. Phaidon:London, 1992.

[21] M. M. Mahamood, Seni Lukis Moden Malaysia: Era Perintis Hingga era Pluralis. Kuaa Lumpur: Utusan Publication \& Distributors Sdn. Bhd, 2001.

[22] H. Read, The Art of Sculpture. Priceton: New York: Bollenge Foundation, 1969.

[23] R. Williams, Culture and Society. London: Chatto \& Windus, 1967.

[24] G. Clifford, Description: towards and Interpretative Theory Of Culture. The Interpretation of culture, 1973. http://www.academic.csuohio.edu/as227/spring2003/geertz.htm.

[25] D. N. Lindsey, Herbert Blumer's Symbolic Interactionism. http://www.colorado.edu/. 